Raf. J. Sci.,Vol.27,No.4 /Special Issue for the Third Scientific Conference of Biology, pp.40-50, 2018

\title{
Bioinformatics: Effect of Cytomegalovirus Infection on Human Immune Gene Expression
}

\author{
Abdulrhem Th. Al-Ghazal \\ Department of Biology/College of Science / University of Mosul \\ Email: bakurius@uomosul.edu.iq
}

(Received $30 / 5 / 2018$; Accepted 1/11/2018)

\begin{abstract}
Cytomegaloviruses (CMV) cause common infections in humans with a prevalence of over $70 \%$ in adults, reaching $90 \%$ in poorer communities and developing countries. In immunecompromised and transplant recipients, CMV causes serious complications including pneumonia and ulcerative colitis. Studying the effect of CMV on human immune-inflammatory genes in immune cellular responses is critically important to explore the molecular mechanisms of viral-host interaction. The aim of this study is to explore changes in the mRNA transcripts of a panel of 84 human inflammatory genes. Ninety blood samples were collected from healthy persons used as control samples and compared with acute infection with CMV sample from bioinformatics data (previous researches). Real time-PCR array were performed to determine mRNA levels expression levels of 84 different cytokines and chemokines in control's leukocytes concentrate. CMV infection caused upregulation (between 44.99 and 0.92 fold change) in the expression of 13 human immuneinflammatory genes (IL-1 alpha, IL10R Alpha, CXCL10, IL10, CX3CR1, CCL2, CCR5, CCR7, CXCL1, IL-1 $\beta$, TNF, IFN-alpha 2, CCL5). Gene ontology analysis revealed that CMV causes high impact on four key pathways in infected cells.
\end{abstract}

Keywords: RT-PCR-arrays; Cytomegaloviruses, inflammatory gene expression, cytokines.

\section{معلوماتية حيوية: تأثير إصابة فيروس المتضخم الخلوي على التعبير الجيني في الإنسان}

\footnotetext{
الملخص

يسبب الفيروس المتضخم الخلوي إصابات عامة ومتعددة للإنسان وبنسبة انتشار تصل الى 70\% في البالغين وتصل الى 90\% في مجتمعات الدول الناميـة. في الأشـخاص ضـعيفي المناعـة والمجرى لهم عمليات نقل اعضـاء، يسبب الفيروس مضاعفات خطيرة مثل ذات الرئة وقرحة القولون. ان دراسـة تأثير إصـابة فيروس المتضخم الخلوي على مستوى التعبير الجيني المناعي الالتهابي داخل خلايا الإنسان تعتبر مهمة لمعرفة طبيعة الميكانيكية الجزيئية الحاصلة بين الفيروس والخلية المضيف. الهدف من هذا البحث هو دراسـة التغيرات الحاصلة في نسـخ الحامض النووي الرايبوزي (التعبير الجيني) ل 84 جين مناعي

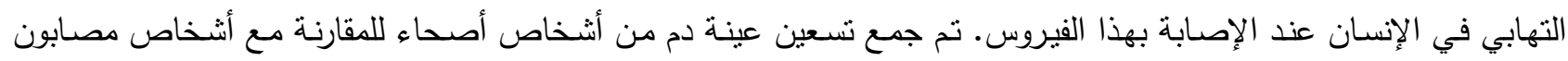
بالفيروس في دراسات سابقة. نم استخدام تقنية تفاعل البلمرة المنسلسل الاني لتحديد مستوى التعبير الجيني (نسخ الحامض النووي الراييوزي) للجينـات المناعيـة في كريـات الدم البيضـاء. أظهرت الدراسـة زيـادة في تضـاعف التعبير الجيني ل 13 جين منـاعي

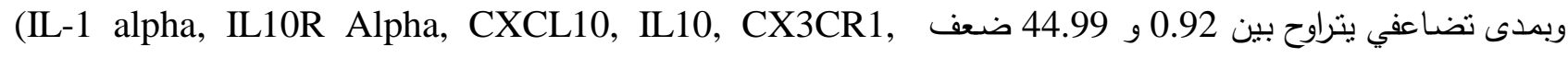
CCL2, CCR5, CCR7, CXCL1, IL-1ß, TNF, IFN-alpha 2, CCL5). تحليلات التتبؤ الجيني اظهرت نأثيرا كبيرا

$$
\text { لفيروس المنضخم الخلوي على اربعة مسارات حيوية مناعية في الخلايا المصابة. }
$$
}




\section{INTRODUCTION}

Viral respiratory tract infections are the most common infectious illnesses, though they are usually self-limiting and confined to the respiratory tract. The rapid recognition of viruses and their effective elimination with minimal local and systemic inflammation is a good indication to the efficiency of the innate immune response within the airways and lungs. Human cytomegaloviruses (CMV) cause ubiquitous infections with seropositivity rates in the US adult population ranging between 40 and 90\%. CMVs infect monocytes and other haematopoietic progenitor cells and cause changing (up or down regulation) in their gene expression (Staras et al., 2006).

The innate immune response to viruses requires their early detection through pathogen recognition receptors and the recruitment of the efficient antiviral response that is centered on the release of type 1 interferon (See and Wark, 2008). Effective communication between the cells of the immune system is essential for the proper functions of a whole complex network. Cells secrete cytokines that mediate signals between cells. These signals lead to alterations in the gene expression by the target cell. Tens of different cytokines can be divided into several groups based on their structure, function, or the structure of the receptors to which they bind (Green, 2000). Cytokines play a key role in the development and functioning of both the innate and adaptive immune response. They are often secreted by immune cells that have encountered a pathogen such as viruses, thereby activating and recruiting immune cells to increase the system's response to the pathogen (David et al., 2008).

Most cytokine effects result from an altered gene expression pattern in the target cells (Vilcek, 2003). It is common for different cell types to secrete the same cytokine or for a single cytokine to act on several different cell types (pleiotropy). Cytokines can also act synergistically (two or more cytokines acting together) or antagonistically (cytokines causing opposing activities) (Khatri et al., 2010).

The manifestations of CMV disease are diverse, and clinical disease is closely linked to immune status of the infected host (Compton, 2004). CMV infection is usually asymptomatic in individuals with normal immune function, whilst infection can have serious consequences for the immunocompromised. Microarray analysis and RT-qPCR are powerful methods to determine global profiles of genes in cells and tissues after viral infections (Clewley, 2004). Development of microarrays facilitated the screening of viral pathogens from across broad viral families (See and Work, 2008; Penelope et al., 2004). Data analysis of Real-time-reverse transcription PCR-array (RT-PCR-array) (SABioscience) is a sensitive and reliable method for gene expression analysis (Montgomery and Daum 2009). Gene Ontology can determine the side effect of these altered genes on the most important immune-inflammatory pathways in patients affected with microbial infections (David et al., 2008). The aim of this study is to determine the human immuneinflammatory gene expression profile after infection with human CMV especially. In addition to specify the up regulated genes and their function during CMV infections.

\section{Blood samples (Control)}

\section{MATERIALS AND METHODS}

Ninety patients hospitalized at Ibn AL-Haytham Hospital in Amman/Jordan for viral infections are included to analyze their gene expression changes in their leukocytes. EDTA-blood (5ml) was collected from 90 patients after complete recovery from viral infection and used as control samples and compared with acute infection with CMV sample from previous researches.

\section{Extraction of mRNA from controls leukocyte}

The RNA is extracted within $24 \mathrm{~h}$ of blood collection as follows: RNA-extraction phase, treat the leukocytes isolated from the blood buffy coat after 30 days of recovery from viral respiratory infections (used as control) with Trizol reagent (Phenol-guanidin-isothiocyanate) (Invitrogen). 


\section{RNA quantitation}

Spectrophotometer (Bio-Rad-USA) analysis is carried out to determine the concentration $(\mu \mathrm{g} / \mathrm{ml})$ of RNA by measuring the optical density (O.D) at $\lambda 260$ and according to the following equation: RNA concentration $=40$ (O.D factor) $\times 25$ (dilution factor) $\times$ O.D at $\lambda 260$. RNA quality is tested using two methods, spectrophotometer (Bio-Rad) and gel-electrophoresis (bands: 28S and 18S). In spectrophotometer the O.D260/280 ratio is checked. RNA is considered pure if the O.D ratio is between 1.8 and 2.0.

\section{RNA efficiency test}

Before performing the RT PCR-Array, the RNA samples are tested for the efficiency of the reverse transcription to produce the cDNA on the RNA samples Fig. (1) using 1.0 $\mu$ g of random primer, PCR components and master mixture (Promega USA).

\section{Real time- PCR array}

Real time-PCR array were performed to quantitate human cytokine and chemokine mRNA levels expression levels of 84 different cytokines and chemokines in control's leukocytes concentrate. Isolated cDNA were synthesized using SABioscince kit. Each cDNA sample was added to RT-qPCR master Mix containing SYBR Green and reference dye (SABioscince). Twenty five $\mu \mathrm{L}$ of cDNA-Master Mix mixture was added to each well across the PCR-arrays. PCR-arrays contain 12 internal gene controls (SABioscince). Thermocycling conditions were $95^{\circ} \mathrm{C}$ for $10 \mathrm{~min}$ and 40 cycles of $\left(95^{\circ} \mathrm{C}\right.$ for $15 \mathrm{sec}, 60^{\circ} \mathrm{C}$ for $\left.1 \mathrm{~min}\right)$ using Bio-Rad-iCycler real-time PCR detection systems.

\section{Real-Time PCR detection}

The threshold cycle values (Ct values) are calculated for each well using iQ cycler Bio-Rad software-USA. Acute $\mathrm{Ct}$ values from different previous studies were calculated according to standard gene expression data (Al-Ghazal, 2010). The data is exported to a blank Excel Spreadsheet for use with SABioscience Data Analysis Template Excel File. Melting curve program (cycle 1,1 repeat, 95C for $1 \mathrm{~min}$. cycle 2, 1 repeat, 55C for $1 \mathrm{~min}$. cycle 3, 80 repeat, 55C for $10 \mathrm{sec}$.) is run immediately after the cycling program, and generates a first derivative dissociation curve for each well in the entire plate. The fold-change is calculated for each gene in control and acute groups as $2^{\wedge}(-\Delta \Delta \mathrm{Ct})$.

\section{Acute samples \\ Gene-Data Collection}

Up regulated immune-inflammatory genes were collected from previous studies after infection with CMV. The collected genes that their gene expression changes (with different fold change) were regarded as the acute sample. The fold changes of genes samples were changed into threshold values $(\mathrm{Ct})$ which represent the initial cycle at which the DNA sample was amplified using Real Time PCR-Array-Data Analysis according to standard tables (Al-Ghazal, 2010) Table 1. 
Table 1: Position, symbol, up/down regulation, $\mathrm{Ct}$ values for inflammatory genes after $\mathrm{CMV}$ infections

\begin{tabular}{|c|c|c|c|c|c|c|c|}
\hline $\begin{array}{c}\text { No } \\
\text { • }\end{array}$ & $\begin{array}{l}\text { Position } \\
\text { on } \\
\text { Array }\end{array}$ & Gene name & Gene symbol & $\begin{array}{c}\text { Up } \\
\text { regulation/ } \\
\text { fold }\end{array}$ & $\begin{array}{c}\text { Down } \\
\text { regulation/ } \\
\text { fold }\end{array}$ & $\begin{array}{l}\text { Ct value } \\
\text { Control }\end{array}$ & $\begin{array}{l}\text { Ct value } \\
\text { Acute }\end{array}$ \\
\hline 1 & B02 & $\begin{array}{l}\text { Chemokine (C-C motif) } \\
\text { ligand } 2\end{array}$ & CCL2 & 2 & & 27.8 & 30.5 \\
\hline 2 & B11 & $\begin{array}{l}\text { Chemokine (C-C motif) } \\
\text { ligand } 5\end{array}$ & $\begin{array}{c}\text { CCL5, } \\
\text { RANTES }\end{array}$ & & -2 & 24.4 & 25.7 \\
\hline 3 & $\mathrm{C} 06$ & $\begin{array}{l}\text { Chemokine (C-C motif) } \\
\text { receptor } 5\end{array}$ & CCR5 & 2 & & 22.8 & 25.2 \\
\hline 4 & $\mathrm{C} 08$ & $\begin{array}{l}\text { Chemokine (C-C motif) } \\
\text { receptor } 7\end{array}$ & CCR7 & 2 & & 21.6 & 24.0 \\
\hline 5 & D01 & $\begin{array}{l}\text { fractalkine-binding } \\
\text { chemokine receptor }\end{array}$ & CX3CR1 & 4 & & 28.7 & 32.6 \\
\hline 6 & D02 & $\begin{array}{l}\text { Chemokine (C-X-C motif) } \\
\text { ligand } 1 \text { (melanoma growth } \\
\text { stimulating activity, alpha) }\end{array}$ & CXCL1 & 2 & & 22.6 & 25.0 \\
\hline 7 & D03 & $\begin{array}{c}\text { Chemokine (C-X-C motif) } \\
\text { ligand } 10\end{array}$ & CXCL10 & 3 & & 24.6 & 29.1 \\
\hline 8 & E02 & Interferon, alpha 2 & IFN-alpha 2 & 2 & & 23.1 & 24.4 \\
\hline 9 & E03 & Interleukin 10 & IL10 & 2 & & 25.6 & 29.9 \\
\hline 10 & E04 & $\begin{array}{l}\text { Interleukin } 10 \text { receptor, } \\
\text { alpha }\end{array}$ & $\begin{array}{l}\text { IL10R } \\
\text { Alpha }\end{array}$ & 2 & & 21.8 & 27.4 \\
\hline 11 & E09 & Interleukin 1, alpha & IL-1 alpha & 2 & & 22.5 & 28.1 \\
\hline 12 & E10 & Interleukin 1, beta & IL-1 $\beta$ & 2 & & 23.7 & 25.0 \\
\hline 13 & G09 & Tumor necrosis factor & TNF & 2 & & 23.6 & 24.9 \\
\hline
\end{tabular}

Table 2: The new fold change values of gene expression compared with control group in

\begin{tabular}{|c|c|c|c|c|c|c|c|c|}
\hline No. & $\begin{array}{c}\text { Position } \\
\text { on Array }\end{array}$ & Genes symbol & $\begin{array}{c}\text { Up } \\
\text { regulation/ } \\
\text { fold }\end{array}$ & $\begin{array}{c}\text { Down } \\
\text { regulation/ } \\
\text { fold }\end{array}$ & $\begin{array}{c}\text { Ct value } \\
\text { Control }\end{array}$ & $\begin{array}{c}\text { Ct } \\
\text { value } \\
\text { Acute }\end{array}$ & $\begin{array}{c}\text { New upregulation } \\
\text { after analysis }\end{array}$ & $\begin{array}{c}\text { Groups } \\
\text { analys }\end{array}$ \\
\hline 1 & E09 & IL-1 alpha & 2 & & 22.5 & 28.1 & 44.9942 \\
\hline 2 & E04 & IL10R Alpha & 2 & & 21.8 & 27.4 & 44.9942 \\
\hline
\end{tabular}

genetic analysis. 


\begin{tabular}{|c|c|c|c|c|c|c|c|c|}
\hline 3 & D03 & CXCL10 & 3 & & 24.6 & 29.1 & 20.9905 & \\
\hline 4 & E03 & IL10 & 2 & & 25.6 & 29.9 & 18.2733 & \\
\hline 5 & D01 & CX3CR1 & 4 & & 28.7 & 32.6 & 13.8486 & \\
\hline 6 & B02 & CCL2 & 2 & & 27.8 & 30.5 & 6.0279 & Moderate \\
\hline 7 & C06 & CCR5 & 2 & & 22.8 & 25.2 & 4.8962 & \\
\hline 8 & C08 & CCR7 & 2 & & 21.6 & 24.0 & 4.8962 & \\
\hline 9 & D02 & CXCL1 & 2 & & 22.6 & 25.0 & 4.8962 & \multirow{2}{*}{ Low } \\
\hline 10 & E10 & IL-1 $\beta$ & 2 & & 23.7 & 25.0 & 2.2842 & \\
\hline 11 & G09 & TNF & 2 & & 23.6 & 24.9 & 2.2842 & \\
\hline 12 & E02 & IFN-alpha 2 & 2 & & 23.1 & 24.4 & 0.9277 & \\
\hline 13 & B11 & CCL5, & & -2 & 24.4 & 25.7 & 0.9277 & \\
\end{tabular}

\section{Calculation of fold change Analysis of Ct values}

The Ct values introduced into gene analysis site (SABioscience-RT-PCR-Array using a Blank Excel Spread-sheet, SABioscience Data Analysis Template Excel File (Campeau et al., 2009; Myskiw et al., 2009). The results of this analysis represent the new fold change values of gene expression compared with the same control group in all genetic analysis. After gene analysis the value of gene expression for each gene was determined; more than one fold (compared with one fold for control genes) regarded as up regulated gene. Gene expression with less than one fold regarded as down regulated gene.

\section{Gene Ontology}

For gene ontology analysis the gene code number (Unigene or Refseq), of up regulated genes (Table 2) interred in the data analysis using David Functional Annotation Bioinformatics Microarray Analysis, Gene-annotation enrichment analysis, Functional annotation clustering, KEGG pathway mapping, and gene-disease association.

\section{RESULTS AND DISCUSSION}

The results showed that CMV infection caused different levels of changes (upregulation) in the expression of 13 human immune-inflammatory genes (Table 2), Fig. (1).

These changes are classified into three groups (Table 2). First: High affected genes include 5 genes (IL-1 alpha and IL10R Alpha: 44.99 fold change, CXCL10: 20.99 fold change, IL10: 18.27 fold change). Second: Moderate affected genes represented by 4 genes (CCL2: 6.02 fold change, CCR5, CCR7 and CXCL1: 4.89 fold change). Third: Low affected genes represented with 4 genes (IL1B and TNF: 2.28 fold change, IFN-Alpha2 and CCL5: 0.92 fold change) (Fig. 2). This means that CMV caused high impact on host human cell by stimulating upregulation of these genes. Fig. (2). 

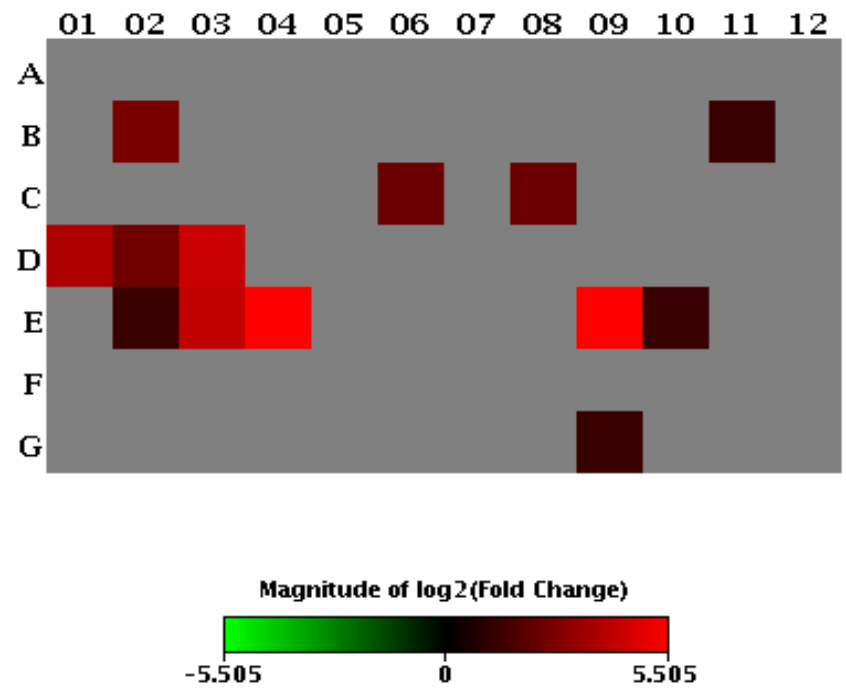

Fig. 1: Heat map for up regulated genes after CMV infection, red color: up regulated genes, green color: down regulated genes, black color: unchanged genes.

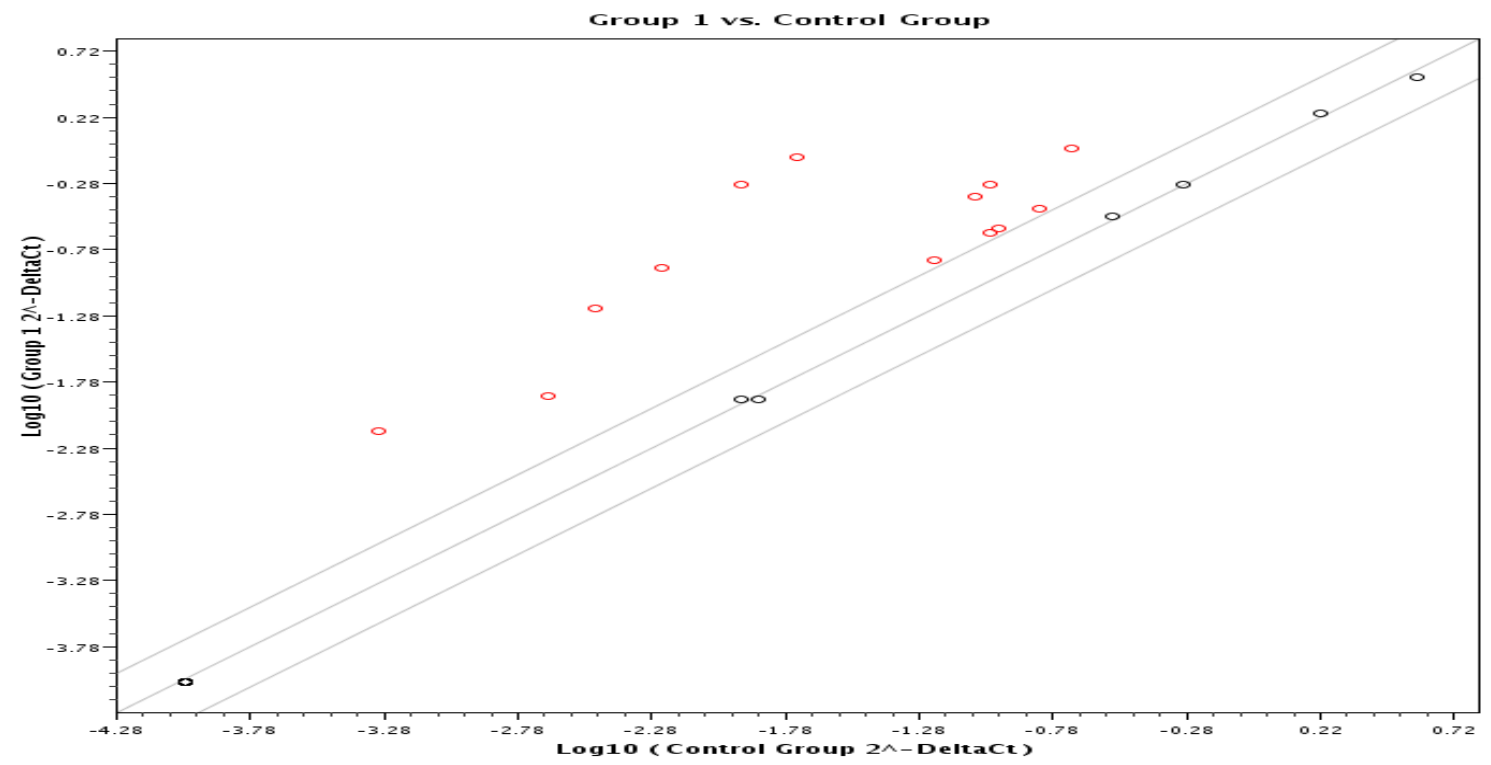

Fig. 2: Scatter plot, Distribution of up regulated genes (circles with red color) according to their fold change, (black color: unchanged genes).

IL-1 alpha cytokine is the highest up regulated gene in this study (44.99 fold change).(Fig. 3). This cytokine is a pleiotropic cytokine involved in various immune responses, inflammatory processes, and hematopoiesis. Our results coinside with previous study which revealed that CMV infection caused high increasing in IL-1alpha transcript (Kasprzak et al., 2002). This increment in expression of IL-1 alpha is induced by CMV infection which stimulates monocytes and macrophages to act against viral infection. 


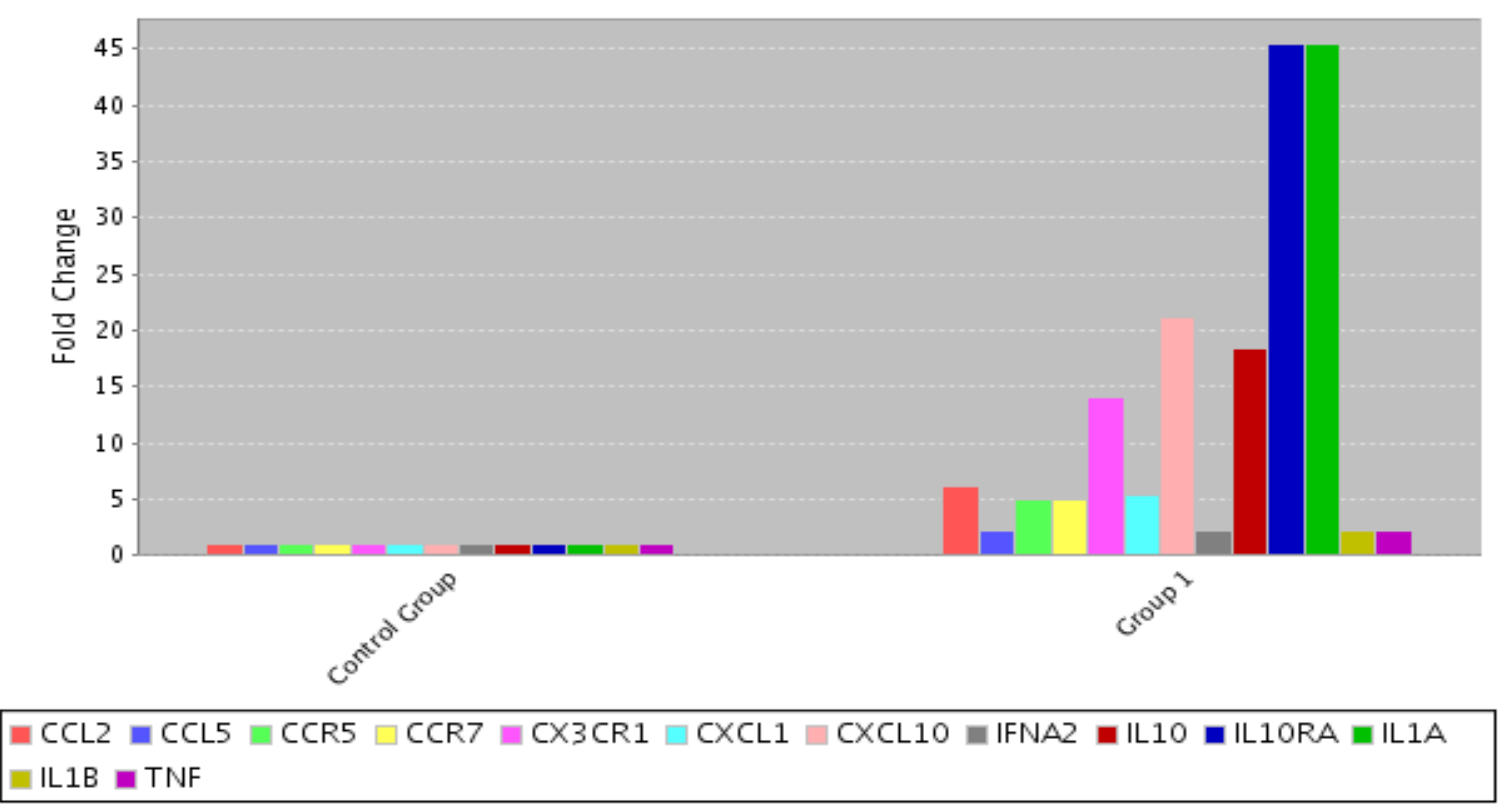

Fig. 3: Histogram plot: Up regulated genes compared with control group (RT-PCR Array laboratory analysis).

IL10R Alpha gene is also up regulated in high rate (44.99 fold change) after CMV infection Fig. (4). Function of this gene is associated with diseases include Inflammatory Bowel Disease and Cytomegalovirus Retinitis. (Ho et al., 1993). Another study revealed that CMV activates production of IL10 receptor alpha similar result (Inkinen et al., 2005). This gene is up regulated by action of CMV to to mediate the immunosuppressive signal of interleukin 10, and thus inhibits the synthesis of proinflammatory cytokines.

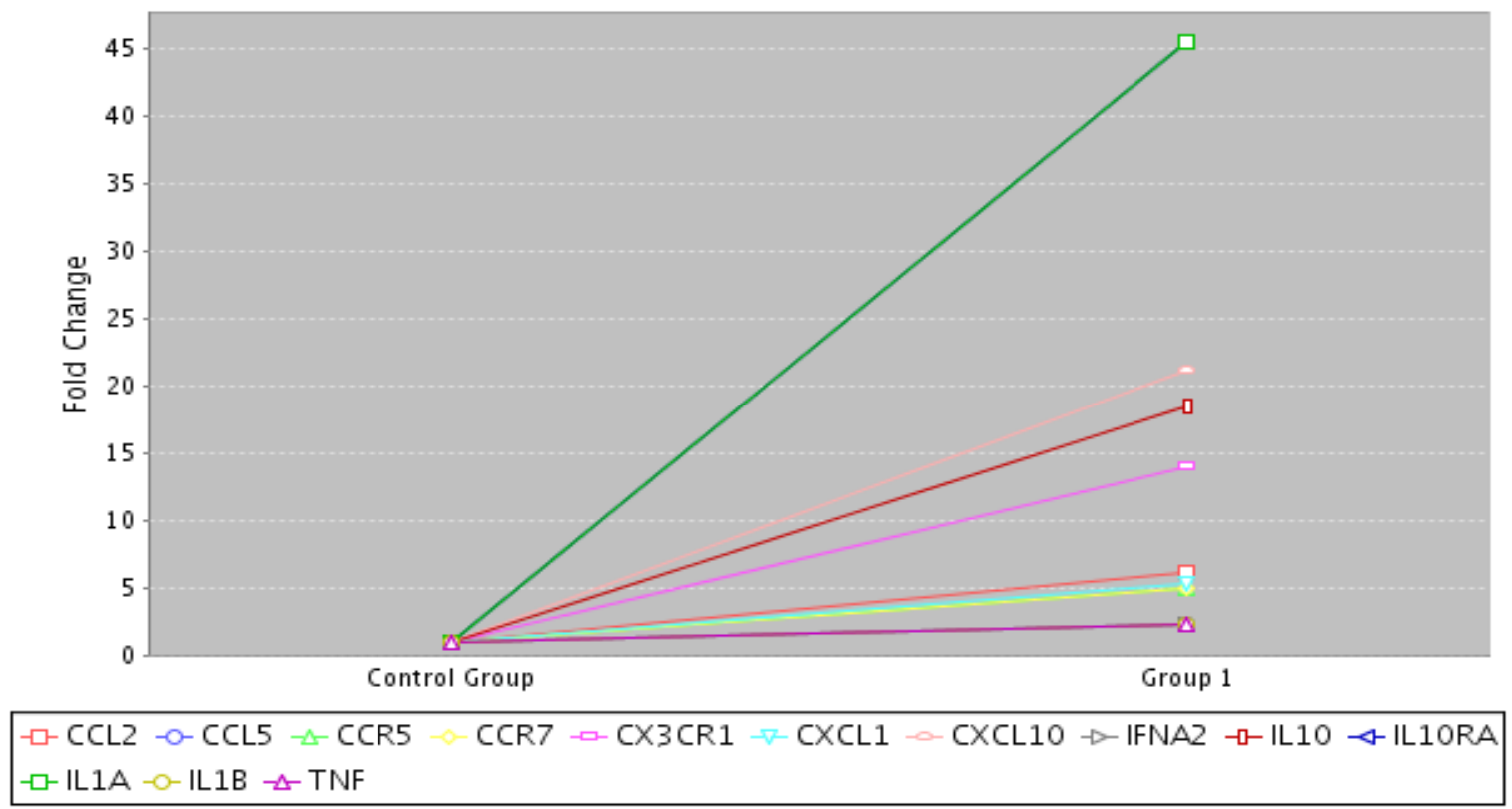

Fig. 4: Curve plot: Up regulated genes compared with control group RT-PCR Array laboratory analysis.

CXCL10 is up regulated with 20.99 fold change in this study Fig. (3, 4), CXCL10 (IFN-cinduced protein 10 or IP-10) mRNA expression is a marker of an intracellular antiviral response (Paladino et al., 2006). Another study showed that CXCL10 (mRNA) up regulated with 2 fold 
change (Staras et al., 2006; Stuart et al., 2013). These results demonstrated that CMV induced modulation of CXCL10 expression was driven by viral replication.

IL 10 gene produces a cytokine by monocytes and lymphocytes. It has pleiotropic effects in immunoregulation and inflammation. It down-regulates the expression of Th1 cytokines, MHC class II Ags. It also enhances B cell survival, proliferation, and antibody production. The results of this study showed that IL10 is up regulated with 18.27 fold change after CMV infection. This result is in agreement with another study which illustrated that LI 10 is up regulated as a result for CMV infection (Inkinen et al., 2005).

In this study CX3CR1 transcript up regulated with 13.84 fold change (Fig. 3, 4). CX3CR1 gene produce Fractalkine protein which is a transmembrane protein and chemokine involved in the adhesion and migration of leukocytes. Previous study showed expression of CX3CR1 during the course of the inflammatory cascade events initiated by the host T-cell response to CMV antigen in the affected cells (Eash et al., 2009; Kolaczkowska and Kubes, 2013). This gene was also upregulated in virus-reactive cells throughout the response (Zhang et al., 2016). Another study used microarray analysis and phenotypic expression revealed moderate expression of CX3CR1 that direct immune cell towards fractalkine after CMV infection (Pachnio et al., 2016).

The chemokine CCL2 (monocyte chemotactic protein-1 or MCP-1) exhibits potent chemotactic activity for monocytes and is a likely target for CMV-induced immunomodulation (Goser et al., 2005). In this study CCL2 gene was up regulated (6.02 fold change) after CMV infection (Fig. 3, 4). Stuart et al., 2013 revealed that CCL2 is up regulated during early stage infection, followed by CCL2 inhibition at late stage infection. This immune modulation may facilitate virus dissemination, establishment of latency and pathogenesis of CMV-induced host disease. other studies showed similar results (van de Berg et al., 2010; Scott et al., 2012; Naing et al., 2015).

CCR5 gene produces protein by $\mathrm{T}$ cells and macrophages, and is known to be an important coreceptor for macrophage-tropic virus. In this study mRNA of CCR5 gene is moderately up regulated (4.89 fold change). Previous study suggested that CMV stimulate upregulation of CCR5 by inducing secretion of soluble factor(s) secreted from HCMV-infected cells (King et al., 2006). Another study showed that CCR5 was down regulated (Moutaftsi et al., 2004) after CMV infection. This disagreement maybe related to different sampling during different periods of infection.

CCR7 function is to stimulate immune cells to respond to viral infection by producing inflammatory chemokines (Moutaftsi et al., 2004). In this study results showed that CMV infection up regulates CCR7 with 4.89 fold change. This increment may be to stimulate migration of dendritic cells into lymph nodes then act against virus (Geissmann et al., 2002). Another study showed that CMV infection increases the expression of the lymphoid-type chemokine receptors, such as CCR7 (Moutaftsi et al., 2004).

Chemokine (C-X-C motif) ligand 1gene (melanoma growth stimulating activity, alpha) function is to regulate the cell trafficking of various types of leukocytes through interactions with a subset of 7-transmembrane $\mathrm{G}$ protein-coupled receptors. It also plays fundamental roles in the development, homeostasis, and function of the immune system (Huang et al., 2009). In this study CXCL1 is up regulated with 4.89 fold change after CMV infection. CXCL1 gene plays a key role in Cytokine-cytokine receptor interaction pathway. In another study, the CXCL1 showed high levels of expression (30.5-fold) during viral infection (Crompton et al., 1988). This variation in fold change may be related to variation of virus titer, type of virus and stage of infection.

$\mathrm{IL}-1 \beta$ gene plays a crucial role in human cytomegalovirus (HCMV) infection. In this study this gene is up regulated with low range of mRNA transcripts (2.28 fold change). A previous study revealed that CMV immediate-early (IE) proteins vigorously trans-activate IL1B expression (Yang et al., 2002). IL1B cytokine is produced by activated macrophages as a pro-inflammatory protein. This cytokine is released during viral inflammation of the central nervous system (Asadullah et al., 2003). 
TNF gene elicits a wide range of biological effects. It is a major mediator of apoptosis as well as inflammation and immunity and has been implicated in a wide range of human diseases (Chen, and Goeddel, 2002). In this study TNF is up regulated with 2.28 fold change in order, perhaps, to influence uninfected cells to be in anti-viral strategy for the virus. Another study showed that CMV activates expression of TNF (Dudding et al., 1989). On other hand Baillie et al., showed that CMV caused down-regulation of TNF expression to prevent the cell from responding to a potent cellular cytokine that acts against virus.

IFN-alpha 2 gene play key role in immune stimulatory genes and in the synthesis and secretion of pro-inflammatory chemokines (Knoblach et al., 2001). In this study CMV infection up regulated IFN-alpha 2 with very low rate $(0.9277$ fold change). This result is almost in agreement with previous study which showed that CMV infection up regulated Interferon with 2-5 fold change ((Knoblach et al., 2001). Another study showed significant upregulation of Interferon after CMV infection (Iwata et al., 1999). This upregulation of interferon gene reflected its importance to stimulate many different pro inflammatory genes to be ready to act against CMVs.

CCL5 gene (RANTES) plays a important role in recruitment of mononuclear cells to the site of viral infection. In this study CCL5 is up regulated with low rate ( 0.9277 fold change). This result is in disagreement with a previous study which revealed that CMV drive infected cell to reduce (down regulate) CCL5 in order to prevent recruitment of mononuclear cells to the site of infection (Schroder and Worthen, 2001). This variation in result may relate to time taking of blood sample (early or late) after infection.

\section{CONCLUSIONS}

CMV infections cause high impact on cellular gene expression and ends up with stimulation of important inflammatory genes which leads to different complications. CMV viruses have different effects on human leukocytes gene expression represented as a viral influence. Gene ontology showed that CMV viruses stimulate four different key inflammatory pathways represented by cytokine-cytokine receptor interaction pathway, NOD-like receptor signaling pathway, Toll-like receptor signaling pathway and asthma pathway.

\section{REFERANCES}

Al Ghazal, A.T. ( 2010). Effect of viral respiratory infection by influenza, A. viruse, parainfluenza and adenoviruse on immune inflammatory gene Expression/ inhibition of Human white Blood cell, Ph.D. Thesis University of Jordan, Jordan, pp.1-214.

AL Ghazal, A.T. (2012). Determination of the changes in human leukocytes inflammatory genes expression after infection with human papillomavirus. Raf. J. Sci., 23(4), 33-50.

Asadullah, K.; Sterry, W.; Volkh, D. (2003). Interleukin-10 therapy-review of a new approach. Pharma. Review, 55, 241-269.

Baillie, J.; Sahlender, D.A.; Sinclair, J.H.(2003). Human cytomegalovirus infection inhibits tumor necrosis factor alpha (TNF-alpha) signaling by targeting the 55-kilodalton TNF-alpha receptor. J. Virol. 77, 7007-7016.

Campeau, P.; Rafei, M.; Boivin, M.; Sun, Y.; Grabowski, G.; Galipeau, J. (2009). Characterization of Gaucher disease bone marrow mesenchymal stromal cells reveals an altered inflammatory secretome. Blood, 114(15), 3181-3190.

Chen, G.; Goeddel, D.V. (2002). TNF-R1 signaling: a beautiful pathway. Science 296, 1634-1635.

Clewley, J. (2004). A role for arrays in clinical virology: fact or fiction. J. Clin. Virol, 29, 2-12.

Compton, T.; Kurt-Jones, EA.; Boehme, KW.; Belko, J.; Latz, E. (2003). Human cytomegalovirus activates inflammatory cytokine responses via CD14 and Toll-like receptor 2. J. Virol., 77, 4588-4596.

Crompton, M.; Moss, E.; Crumpton, J. (1988). Diversity in the lipocortin/calpactin family. Cell, 55(1), 1-3. 
David, F.; Farley, J.; Huang, H.; Lavoie, J.; Laverty, S. (2008). Cytokine and chemokine gene expression of IL-1beta stimulated equine articular chondrocytes. Vet. Surgery, 37(5), 499.

Dudding, L.; Haskill, S.B.; Clark, D.P.; Auron, E.; Sporn, S.; Huang, E.S. (1989). Cytomegalovirus infection stimulates expression of monocyte-associated mediator genes. J. Immunol. 143, 3343-3352.

Eash, K.J.; Means, J.M.; White, D.W.; Link, D.C. (2009). CXCR4 is a key regulator of neutrophil release from the bone marrow under basal and stress granulopoiesis conditions. Blood. 113, 4711-4719.

Geissmann, F.; Dieu-Nosjean, M.C.; Dezutter, C.; Valladeau, J.; Kayal, S.; Brousse, M.N.; Saeland, S.; Davoust, J. (2002). Accumulation of immature Langerhans cells in human lymph nodes draining chronically inflamed skin. J. Exp. Med. 196, 417-430.

Goser, S.; Ottl, R.; Brodner, A.; Dengler, T.J.; Torzewski, J.; Egashira, K.; Rose, N.R.; Katus, H.A.; Kaya, Z. (2005). Critical role for monocyte chemoattractant protein-1 and macrophage inflammatory protein-1a in induction of experimental autoimmune myocarditis and effective anti-monocyte chemoattractant protein-1 gene therapy. Circulation , 112, 34003407.

Green, D.R. (2000). Apoptotic Pathways: paper wraps stone blunts scissors, Cell, 102:1-4. Ho AS, Liu Y, Khan TA, Hsu DH, Bazan JF, Moore KW (December 1993). "A receptor for interleukin 10 is related to interferon receptors". Proc. Natl. Acad. Sci. U.S.A. 90 (23), 11267-71. doi:10.1073/pnas.90.23.11267. PMC 47963Freely accessible. PMID 8248239.

Huang, D.; Sherman, B.; Lempicki, R. (2009). Systematic and integrative analysis of large gene lists using DAVID Bioinformatics Resources. Nature Protocol, 4(1), 44-57.

Inkinen, K.B.; Lahesmaac, B.A.; Katajamaac, M.; Halmea, L.; Höckerstedta, K.; Lautenschlage, I. (2005). DNA Microarray-Based Gene Expression Profiles of Cytomegalovirus Infection and Acute Rejection in Liver Transplants. Inter. Virol. 37(2), Pages 1227-1229.

Iwata, M1.; Vieira, J.; Byrne, M.; Horton, H.; Torok-Storb, B. (1999). Interleukin-1 (IL-1) inhibits growth of cytomegalovirus in human marrow stromal cells: inhibition is reversed upon removal of IL-1. Blood. 15, 94(2), 572-8.

Kasprzak, A.; Zabel, M.; Jacek, W.; Filipiak, B. (2002). Expression of mRNA for cytokines (TNFalpha and IL-1 alpha) in human cytomegalovirus (HCMV) and hepatitis B virus (HBV) infections. Folia Histoch. Cyto., 40 (2),63-68

Khatri, M.; Brien, T.; Goyal, S.; Sharma, J. (2010) Isolation and characterization of chicken lung mesenchymal stromal cells andtheir susceptibility to avian influenza virus. Develop. and Comp. Immunol., 34, 474-479.

King, CA.; Baillie, J.; Sinclair, JH. (2006). Human cytomegalovirus modulation of CCR5 expression on myeloid cells affects susceptibility to human immunodeficiency virus type 1 infection. J. Virol. 12 (3), 33-40.

Knoblach, Th.; Grandel, B.; Seiler, J.; Nevels, M.P. (2011). Human Cytomegalovirus IE1 Protein Elicits a Type II Interferon-Like Host Cell Response That Depends on Activated STAT1 but Not Interferon- $\gamma$. PLoS Pathog. 7(4), e1002016. doi: 10.1371/journal. ppat.1002016.

Kolaczkowska, E.; Kubes, P. (2013). Neutrophil recruitment and function in health and inflammation. Nat. Rev. Immunol. 13, 159-175.

Montgomery, C.; Daum, R. (2009). Transcription of inflammatory genes in the lung after infection, Inf. Immunol, 77(5), 2159-67.

Moutaftsi, M.; Brennan, P.; Stephen, A.; Spector; Z.T. (2004). Impaired lymphoid chemokinemediated migration due to a block on the chemokine receptor switch in human cytomegalovirus-infected dendritic cells. J. Virol. Mar; 78(6), 3046-3054.

Myskiw, C.; Arsenio, J.; Van Bruggen, R.; Deschambault, Y.; Cao, J. (2009). Vaccinia virus E3 suppresses expression of diverse cytokines through inhibition. J. Virol, 83(13), 6757-68. 
Naing, Z1.; Webel, R.; Hamilton, S.; Schmeiser, C.; Scott, G.; Marschall, M. (2015). Rawlinson Stimulatory effects of human cytomegalovirus tegument protein pp71 lead to increased expression of CCL2 (monocyte chemotactic protein-1) during infection. J. Gen. Virol.; 96(Pt 7), 1855-62.

Pachnio, A.; Ciaurriz, M.; Begum, J.; Lal, N.; Zuo, J.; Beggs, A.; Moss, P. (2016) Cytomegalovirus infection leads to development of high frequencies of cytotoxic virusspecific cd4+ $\mathrm{t}$ cells targeted to vascular endothelium. http://dx.doi.org/10.1371/J. ppat.1005832.

Paladino, P.; Cummings, D.T.; Noyce, R.S.; Mossman, K.L. (2006). The IFN-independent response to virus particle entry provides a first line of antiviral defense that is independent of TLRs and retinoic acidinducible gene I. J. Immunol.177, 8008-8016.

Penelope, A.; Bryant, D.; Roy, R.; Nigel, C. (2004). Chips with everything: DNA microarrays infectious diseases. Lan. Inf. Dis., 4, 100-111.

Schroeder, B.M.; Worthen, S. (2001). Viral Regulation of RANTES expression during human cytomegalovirus infection of endothelial cells program of cell biology. J. Virol., 0022538X/01/\$04.0010 DOI: 10.1128/JVI.75.7.3383-3390.

Scott, G.M.; Chow, S.S.; Craig, M.E.; Pang, C.N.; Hall, B.; Wilkins, M.R.; Jones, C.A.; Lloyd, A.R.; Rawlinson, W.D. (2012). Cytomegalovirus infection during pregnancy with maternofetal transmission induces a proinflammatory cytokine bias in placenta and amniotic fluid. J. Infect. Dis. 205, 1305-1310.

See, H.; Wark, P. (2008). Innate immune response to viral infection of the lungs, Paediatric Respiratory Reviews, 9, 243-250. Vilcek A., (2003). Novel interferons. Nature Immunol., 4, 8-9.

Staras, S.A.; Dollard, S.C.; Radford, K.W.; Flanders, W.D.; Pass, R.F.; Cannon, M.J. (2006). Seroprevalence of cytomegalovirus infection in the United States, 1988-1994. Clin. Infect. Dis. 43, 1143-1151.

Stuart, T.; Hamilton, G.M.; Scott, Z.N.; William D.H. (2013). Cytomegalovirus directly modulates expression of chemokine CCL2 (MCP-1) during viral replication Rawlinson. J. Gen. Virol. 94, 2495-2503.

van de Berg, P.J.; Heutinck, K.M.; Raabe, R.; Minnee, R.C.; Young, S.L.; Van Donselaar-van der Pant, K.A.; Bemelman, F.J.; Van Lier, R.A.; Ten Berge, I.J. (2010). Human cytomegalovirus induces systemic immune activation characterized by a type 1 cytokine signature. J. Infect. Dis. 202, 690-699.

Yang, Zh.; Wara-aswapati, N.; Yoshida, Y.; Walker, N.; Galson, D.; Listman, J.; Auron, P. (2002) Dual regulatory role of human cytomegalovirus immediate-early protein in IL1B transcription is dependent upon Spi-1/PU. Bioch. Bioph. Res. Com.. 294, 4, 21, Pages $854-863$.

Zhang, X.; Zhang, Zh.; Yuan, Zh. (2016). Citation Information. J. Clin. Invest. doi: 10. 1172/JCI83339. 